УДК:377.8.

DOI 10.33514/1694-7851-2019-2-162-166

Сыдыков Базарбек Кимбилдиевич

И.о. профессора кафедры Музыки КГУ им. И.Арабаева

\author{
ПЛАСТИКАЛЫК АНАТОМИЯ ЖАНА СУРӨТ САБАГЫНЫН \\ КӨРКӨМ БИЛИМ БЕРУУ БАГЫТЫНДА ПЕДАГОГИКАЛЫК МАКСАТЫ \\ ПРЕДМЕТ ПЛАСТИЧЕСКОЙ АНАТОМИИ И РИСУНКА КАК \\ ПЕДАГОГИЧЕСКАЯ ЦЕЛЬ В ОБРАЗОВАНИИ ХУДОЖЕСТВЕННОГО \\ НАПРАВЛЕНИЯ
}

\title{
THE SUBJECT OF PLASTIC ANATOMY AND DRAWING AS A PEDAGOGICAL OBJECTIVE IN EDUCATION, ARTISTIC DIRECTION
}

Аннотация: Курс «Пластическая анатомия» играет важную роль в деле профессиональной подготовки студентов. Цель изучения «Пластической анатомии»изучить основы анатомии человека и сформировать представление о пластике человеческого тела в покое и движении. Изучение анатомии человеческого тела позволяет сформировать образно-пластический способ мышления и от внешнего поверхностного восприятия человека и слепого копирования его форм перейти к глубокому изображению, опирающемуся на знание закономерностей внутренней структуры.

Аннотация: Көркөм искусство багытына билим алып окуган студенттер Үчүн пластикалык аннатомия жана сүрөт сабагынын ээлеген орду чон.

Пластикальк аннатомия жана сүрөт сабагын окуттунун биринчи максаты, кишинин анатомияльк түзүлүшүн терен изилдөөгө алуу. Ошону менен бирге эле адам баласынын кыймыл аракетин изилдөөгө алууга жардам берет.

Кишинин кыймыл аракети катылкан ар бир иш-аракетти туура сүрөтөөгө мүмкүн болот. Демек көркөм искусство багытында билим алган студентер үчүн пластикальк аннатомия жана сүрөт сабагы өтө мааанилүY катары бааланган предмет болуп саналат.

Abstract: plastic anatomy course "plays an important role in the training of students. The purpose of the study "Plastic Anatomy-learn the basics of human anatomy and form an idea about the plastic human body at rest and motion. Study of the anatomy of the human body enables a metaphorically-plastic way of thinking and from the outer surface of the human perception and blind copy forms go to deep image, based on the knowledge of patterns internal structure.

Ачкыч сөздөр: Пластикальк анатомия, сүрөт, педагогика, максат, композиция, илим, билим, кишинин дене түзүлүшү, закон ченемдүүлүк, көлөм, структурасы, фактурасы, табиаты, материалдуулук, көркөм искусство, искусствонун тарыхы, компетенциясы, чыгармачылык, өзүн өзҮ окутуу, изденүү, чыгарма жаратуу проиесстери

Ключевые слова: Пластическая анатомия, рисунок, педагогика, иель, композиция, знания, наука, пластика человеческого тела, закономерность, форма, содержания, структура, фактура, материальность, художественное произведения, история искусства, компетеничи, творчество, самообразования, саморазвития, творческий прочесс

Keywords: Plastic Anatomy, drawing, pedagogy, purpose, composition, knowledge, science, human body, plastic pattern, shape, content, structure, texture, physicality, art works, art history, competence, creativity, self-education, self development, creative process 
Задачи дисциплины пластическая анатомия и рисунок: познакомить студентов основами анатомии опорно-двигательного аппарата; изучить пластику тела человека в покое и движении; рассмотреть основные пропорциональные особенности строения тела человека; содействовать формированию приемов и навыков эстетической оценки и адекватного анализа произведений живописи; показать взаимосвязь знаний основ анатомии и художественного процесса; показать возможность применения полученных знаний на практических занятиях по рисунку, живописи и скульптуре. Компетенции обучающегося, формируемые в результате освоения дисциплины «Пластическая анатомия». «В результате освоения дисциплины обучающийся должен: Готовность к саморазвитию, самореализации, исполнению творческого потенциала»:[1]

- Знать: - некоторые средства саморазвития и повышения мастерства; - мало уровней профессиональной компетенции; - не до конца осознает ценность профессиональной деятельности; - средства саморазвития и повышения мастерства; уровни профессиональной компетенции; - ценность профессиональной деятельности; методы самоанализа профессиональных знаний, умений и навыков;

- Уметь: -определять некоторые средства саморазвития и повышения мастерства; - самостоятельно находить мало информации для повышения культурного уровня и профессиональной компетенции в области анатомического рисунка; - не до конца осуществляет практическую и познавательную деятельность по собственной инициативе; - определять средства саморазвития и повышения мастерства; - самостоятельно находить информацию для повышения культурного уровня и профессиональной компетенции в области анатомического рисунка; - осуществляет практическую и познавательную деятельность по собственной инициативе; - осуществлять самоанализ профессиональных знаний, умений и навыков;

- Владеть: - не всеми средствами саморазвития и повышения мастерства; - малым стремлением к самообразованию для повышения культурного уровня и профессиональной компетенции в области анатомического рисунка; - средствами саморазвития и повышения мастерства; - стремлением к самообразованию для повышения культурного уровня и профессиональной компетенции в области анатомического рисунка; - самоанализом профессиональных знаний, умений и навыков;

Способность создавать на высоком художественном уровне авторские произведения во всех видах профессиональной деятельности, используя теоретические, практические знания и навыки, получение в процессе обучения.

- Знать: - как изобразить фигуру человека, его пропорции, строение; - как грамотно изобразить фигуру человека, его пропорции, пластику, строение; - используя полученные знания и умения, анализировать анатомию фигуры человека, его костную и мышечную основу;

- Уметь: - схематично выполнять рисунки костей скелета человека и понимать основные конструктивные особенности построения головы, и фигуры человека; схематично применять на практике знания анатомического рисунка и пластической анатомии в аспекте изображения фигуры человека; - выполнять рисунки костей скелета человека и понимать конструктивные особенности головы, верхнеплечевого пояса, рук, кистей, грудной клетки, позвоночника, таза, ног, стоп; - применять на практике знания пластической анатомии в аспекте изображения фигуры человека; - врисовать кости скелета в гипсовую анатомическую фигуру; - изображать фигуру человека в движении с пластической и конструктивной взаимосвязью всех мышечных масс; - рисовать по памяти и представлению;

- Владеть: - способностью применять техники конструктивного и академического рисунка при изображении скелета и фигуры человека; - способностью профессионально применять техники конструктивного и академического рисунка при изображении скелета и фигуры человека; - свободным рисованием фигуры человека по памяти и 
представлению; - свободность применять полученные теоретические знания в области перспективы, анатомии, теории и истории изобразительного искусства, материальной культуры, знанием художественных материалов, техник и технологий, используемых в творческом процессе художника-скульптора

\section{- Знать: - основы пластической анатомии;}

1) Уметь: - выражать свой творческий замысел средствами изобразительного искусства и скульптуры, применяя знания по пластической анатомии; - целенаправленно, в соответствии с замыслом произведения, собирать натурный материал в виде рисунков, эскизов, набросков, этюдов и штудий, применяя знания по пластической анатомии;

2) Владеть: - различными техниками рисунка и наброска; знаниями пластической анатомии, в своей практической и творческой работе.

«Освоение дисциплины «Пластическая анатомия» осуществляется одновременно или предшествует изучению дисциплин «Рисунок», «Скульптура», «Анатомический рисунок»»» [2]. Логическая и содержательно-методическая взаимосвязь с данными дисциплинами прослеживается в формировании у студентов научно обоснованного представления о единстве и целостности большой аналитической формы (человеческой фигуры в целом), о пропорциональной зависимости большой и малых форм (фигуры и ее частей), о методах грамотного подхода к изображению большой и малых форм при построении рисунка фигуры человека.

При изучении дисциплины «Пластической анатомии» необходимо постоянно обращать внимание студентов на ее характер, показывать, где и когда изучаемые теоретические положения могут быть использованы при изучении «Скульптура», «Композиция», «Монументальная скульптура», «Станковая скульптура» и в будущей практической деятельности.

«Логическая и содержательно-методическая взаимосвязь с данными дисциплинами содержится в усвоении законов, управляющих движением частей и целого, игры анатомических образований, определяющих формы со всем бесконечным разнообразием их характера и движений; умении решать художественно-творческие задачи по созданию художественных образов в разном материале на основе антропометрии» [3]. Изучение «Пластической анатомии» способствует развитию созидательных творческих способностей в раскрытие сущности и специфики фигуры человека, что позволит в дальнейшем применять полученные знания и умения в профессиональной деятельности. «Дисциплина «Пластическая анатомия» базируется на знаниях, полученных в общеобразовательных учреждениях по предмету «Биология» (раздел «Человек»). 3. Дидактические единицы Основные темы: Общий обзор внешних форм. Элементы строения тела» [4].

Пластическая анатомия головы Остеология. Учение о соединениях костей. Прерывные соединения костей Учение о мышцах. Простейшие механизмы мышечной работы. Костные элементы мозгового черепа. Костные элементы лицевого черепа. Конструктивные и функциональные особенности черепа Соединения костей черепа. Мышцы головы. Мимические мышцы.

Пластическое значение деталей головы. Орган зрения. Нос, рот, наружное ухо. Зубочелюстной аппарат человека. Костная основа туловища. Позвоночный столб. Строение грудной клетки. Соединения туловища. Подвижность позвоночника, осанка. Скелет и соединения плечевого и тазового пояса. Мускулатура шеи. Органы шеи. Мускулатура груди, плечевого пояса, живота, спины. Возрастные и половые особенности формы груди. Пластика и топография живота, спины. Скелет верхней конечности (плечо, предплечье, кисть) Соединения плеча, предплечья, кисти. Мускулатура плеча, предплечья, кисти. Топография верхней конечности.

«Обучающейся студенты и так же должны знать для построения человеческого тела: «Скелет нижней конечности (бедро, голень, стопа) Соединения бедра, голени, стопы. Мускулатура бедра, голени, стопы. Топография нижней конечности. Внешний покров 
тела человека. Придатки кожи. Рельефная анатомия головы, шеи, груди, живота, спины, руки и ноги. Возрастные и половые особенности рельефа человеческого тела Элементы статики и динамики тела человека» [5].

А самое главное понятие о скелете:

1.Понятие о скелете Суставы и другие виды соединений костей между собой.

2. Позвоночник, грудная клетка. Их опорные костные точки.

3. Собственно туловище как единое, подвижное целое.

4. Взаимосвязь тела, позвоночника, грудной клетки.

5. Изменения положения тела стоя, сидя, развалившись.6. Таз - центральное звено построения фигуры.

7. Бедренная кость, её рельеф на модели.

8. Движения в тазобедренном суставе.

9. Кости голени и их рельеф на модели.

10. Движения в коленном суставе и его рельеф на модели.

11. Кости стопы и их рельеф на модели; свод стопы, опорная роль стопы, пальцев.

12. Движения в голеностопном суставе и в суставах стопы.

13. Движения голени и всего тела относительно стопы.

14. Пронация и супинация стопы.

15. Запястье, пясть, фаланги пальцев.

16. Рельеф запястья; гороховидная кость, лучевое возвышение запястья; рельеф пястья.

17. Суставы кисти.

18. Движения плечевого пояса и в плечевом суставе.

19. Движения в локтевом суставе, супинация и пронация.

20. Движения в лучезапястном суставе.

21. Движения в суставах кисти.

22. Особая роль пястно - запястного сустава I пальца.

23. Лопатка и ключица, их рельеф на модели.

24. Суставы плечевого пояса, ярёмная впадина.

25. Понятие о плечевом поясе. Плечевая кость, её рельеф на модели, плечевой сустав.

26. Локтевая и лучевая кости, их рельеф на модели.

27. Локтевой сустав. Соединения между костями предплечья.

28. Пронация и супинация руки.

29. Череп мозговой. Череп лицевой.

30. Кости черепа: затылочная, височная, теменная, лобная, скуловая, верхнеечелюстная, нижняя челюсть.

31. Глазницы, отверстия носа, рта.

32. Методика построения черепа; «крестовина» и др. основные координаты построения черепа.

33. Возрастные и половые особенности черепа.

34. Передние мышцы голени.

35. Задние поверхностные и задние глубинные мышцы голени.

36. Малоберцовые мышцы.

37. Мышцы стопы.

38. Границы таза и живота.

39. Три мышечных массива бедра.

40. Изменения формы коленного сустава и роль надколенника.

41. Мышцы плеча.

42. Описание подмышечной впадины.

43. Механизм передвижения лопатки.

44. Мышечное возвышение большого пальца и мизинца на кисти. 
45. Ладонные и тыльные межкостные мышцы, их действие на пальцы.

46. Кожные и другие покровы кисти.

47. Движения плечевого пояса.

48. Совместные движения плечевого пояса и руки.

49. Неизменность формы грудной клетки.

50. костная и мышечная основа плечевого пояса.

51. Веерообразный свод - основная конструкция кисти.

52. Роль запястья при построении кисти с предплечьем.

53. Два основных массива мышц предплечья и их границы.

54. Группа сгибателей предплечья.

55. Группа разгибателей предплечья.

56. Фиксация кисти.

57. Трапецевидная мышца.

58. Грудино - ключично - сосцевидная мышца.

59. Основные принципы построения шеи с головой вверх от ярёмной впадины, от седьмого шейного позвонка и плечевого пояса и обратно.

60. Мышцы жевательные и мышцы мимические.

61. действие лобных мышц в сочетании с раскрытием глазной щели.

62. Мышцы лица - угрозы, боли, презрения и т.д.

Анатомический анализ положений стоя, сидя, лежа. Анатомическая характеристика поступательных движений тела. История развития учений о пропорциях тела человека. Современные каноны пропорций тела человека. Учение о конституции тела человека. Симметрия и асимметрия тела человека.

\section{Список использованной литературы:}

1. Ювалова Е.П. Немецкая скульптура. М.,2015. Стр.53 [1]

2. Сакулина Н.П. Методика обучения рисованию, лепке и апликации. М.,1966.Стр.11 [2]

3. Крымов Н.П. Художник и педагог. Статьи, воспоминания. М.,1961. Стр.85 [3]

4. Орловский Г.И. Учитель изобразительного искусства и его работа. Некоторые размышления о профессии. М.,1972. Стр.5 [4]

5. Ирвинг Стоун. Муки и радости Микеланджело. М.,2011. Стр.77 [5]

\section{Рецензент: к.ф.н., доцент Самыйканоы А.Т.}

